\title{
Cinnamon powder: an in vitro and in vivo evaluation of antifungal and plant growth promoting activity
}

\author{
Jolanta Kowalska • Józef Tyburski • \\ Joanna Krzymińska • Magdalena Jakubowska
}

Accepted: 18 October 2019/Published online: 14 November 2019

(C) The Author(s) 2019

\begin{abstract}
In this study, the effects of organic powder of Cinnamomum zeylanicum on the development of Botrytis cinerea and its influence on tomato plants were evaluated. The cinnamon bark powder and its water suspensions and filtrates were used at 0.5 and $1 \%$ rates. After 6 days of the start of an in vitro experiment the mycelium growth was inhibited by both 0.5 and $1 \%$ cinnamon water filtrates - to a greater degree in the case of the higher concentration, by 54.4 and $81.4 \%$, respectively. Spraying with cinnamon water filtrates positively influenced the growth of plants both in the greenhouse and the field. Antifungal activity of cinnamon was proved in the greenhouse tests - the disease symptoms of grey mould on infected tomato plants decreased. The fresh weight of non-inoculated tomato plants treated with cinnamon filtrates was significantly higher than control plants (17.17 g compared to $12.83 \mathrm{~g}$ ) showing a stimulating effect of cinnamon filtrates. In the case of inoculated plants due to treatment, their weight increased from 7.83 to $10.50 \mathrm{~g}$. In the field experiment, tomato plants sprayed six times with cinnamon were better developed than the control plants. The most significant effect was observed for Hamlet variety - the mean number of leaves was higher by $27.3 \%$ and the
\end{abstract}

J. Kowalska · J. Krzymińska $(\bowtie) \cdot$ M. Jakubowska Institute of Plant Protection National Research Institute, 20 Władysława Weggorka Street, 60-318 Poznań, Poland e-mail: j.krzyminska@iorpib.poznan.pl

J. Tyburski

University of Warmia and Mazury in Olsztyn, 2 Michała

Oczapowskiego Street, 10-719 Olsztyn, Poland mean number of branches by $19.7 \%$ compared to the untreated control plants. Thus it was proved that cinnamon powder has potential to inhibit $B$. cinerea growth and also has a stimulating effect for tomato plants.

Keywords Botrytis cinerea $\cdot$ Basic substance . Mycelium growth inhibition - Grey mould symptoms inhibition · Tomato vegetative development

\section{Introduction}

There is a worldwide trend to explore new alternatives to control plant diseases, giving priority to methods that reduce disease symptoms and avoid negative side effects on human health resulting from excessive application of synthetic fungicides. The use of food substances, which are also classified as basic substances, demonstrating a protective action in growing crops, is an alternative method for organic farmers or sustainable agriculture farms.

The possibility of limiting the development of pathogenic fungi by applying agents, which are natural and alternative to pesticides, is a popular research direction. But also the use of plants or plant products as fungicides has been of a great importance for some time and needs more attention (Zaker 2016). New pesticides, including natural product-based pesticides are being discovered and developed to replace the compounds lost due to the new registration requirements (Regulation (EC) No1107/2009 of the European Parliament and of the Council of 21 October 2009 concerning the placing of 
plant protection products on the market and repealing council directives 79/117/EEC and 91/414/EE' 2009). The use of natural products is one of biological control methods in fungal disease control. The method is still not common and investigations are required to find suitable plants that can be used to control pathogenic fungi (El-Mougy Nehal and Abdel-Kader Mokhtar 2007; Kowalska 2011; Remlein-Starosta et al. 2016).

Antifungal activity of essential oils (EOs) such as cinnamon, marigold, basil and spearmint was assessed against pathogens such as Botrytis cinerea Pers., Fusarium gramineraum Corda, Fusarium oxysporum Schltdl. and Sclerotinia sclerotiorum (Lib.) de Bary (KocicTanackov et al. 2011; Al-Taisan et al. 2014; Ghalem 2016). The use of EOs and various plant extracts is aligned with current thinking on the future of agriculture in the EU, and with consumer preference for natural products (Brenes and Roura 2010). The antimicrobial properties of EOs have been widely reported (Dorman and Deans 2000; Mourey and Canillac 2002; Rota et al. 2004). Besides antibacterial properties, EOs or their components have exhibited anti-parasitic (Pandey et al. 2000; Pessoa et al. 2002), and insecticidal (Konstantopoulou et al. 1992; Karpouhtsis et al. 1998) properties. EOs are widely used in various fields, including the cosmetics, pharmaceutical, and food industries (Harkat-Madouri et al. 2015). The constituents of these compounds have antibacterial, viricidal, fungicidal, anti-parasitic, insecticidal, and medicinal properties which are considered to be plants protectants (Bakkali et al. 2008).

Cinnamon oils and extracts showed good antifungal properties against important plant diseases. Wilson et al. (1997) found that among 49 essential oils tested, Cinnamomum zeylanicum J. Presl demonstrated a great antifungal activity against $B$. cinerea. Cinnamomum zeylanicum commonly known as cinnamon, refers to a tropical evergreen tree as well as a bark that is extracted from the plant. Substances such as cinnamon have been known to the mankind for a very long time. They are universally recognized as harmless and safe for human consumption. Cinnamon powder is considered to have high potential as a biological control agent (Sikes et al. 2005; Xing et al. 2010; Kocić-Tanackov and Dimić 2013).

B. cinerea Pers. Fr. (teleomorph Botryotinia fuckeliana (de Bary) Whetzel) is an economically important phytopathogenic fungus and a cause for a broad spectrum of plants diseases (van Kan 2006; Bolton et al.
2006; Dean et al. 2012). It can cause serious damage in over 200 plant species both in pre- and post-harvest stages and is difficult to control due to various modes of attack and many hosts (Williamson et al. 2007). Very few reports concerning the use of commercially available powdered cinnamon can be found in the literature. Therefore, the aim of the study was to evaluate the potential of commercially available cinnamon powder originating from organic crops used in the liquid form in different concentrations as a control agent against $B$. cinerea and growth stimulator in both in vitro and in vivo conditions.

\section{Materials and methods}

Plant pathogenic fungus preparation

For all tests $B$. cinerea strain 2235 (plant source: tomato stem) from the Bank of Plant Pathogens in the Institute of Plant Protection, Poland, collection was used. Pure cultures were maintained on Potato Dextrose Agar, Sigma-Aldrich (PDA) media at $4{ }^{\circ} \mathrm{C}$ and sub-cultured at monthly intervals. Ten days old cultures were used for the in vitro experiment.

For the greenhouse and field experiments conidia were harvested from ten days old cultures. The concentration was determined using the Thoma slide and adjusted to $3.1 \times 10^{5} \mathrm{ml}^{-1}$. The resulting suspension was used to inoculate the plants.

\section{Cinnamon suspensions and filtrates preparation}

The preparation method was developed by the authors. Commercially available organic cinnamon (C. zeylanicum) powder (manufactured by Dary Natury, Grodzisk Poland and certified by Ekogwarancja PTRE sp. z o.o.) was used to obtain water suspensions and filtrates. For the in vitro experiment modified PDA media was used. The cinnamon suspensions were prepared using warm sterile distilled water $\left(26^{\circ} \mathrm{C}\right)$ and added to PDA media to obtain 0.5 and $1 \%$ cinnamon PDA suspensions $(0.5$ and $1 \mathrm{~g}$ of cinnamon added to $20 \mathrm{ml}$ of water and $80 \mathrm{ml}$ of the PDA media, respectively). Later cinnamon water suspensions were filtered through a nylon flour mesh $(150 \mu \mathrm{m})$ and added to PDA to obtain 0.5 and $1 \%$ cinnamon filtrates PDA suspensions $(0.5$ and $1 \mathrm{~g}$ of cinnamon powder added to $20 \mathrm{ml}$ of water, filtrated; $20 \mathrm{ml}$ of the filtrate added to $80 \mathrm{ml}$ of 
the PDA media). For the greenhouse and field experiments $0.5 \%$ water filtrate was used. Five grams of cinnamon was added to 11 of warm tap water $\left(26^{\circ} \mathrm{C}\right)$ and filtered through a flour mesh. The filtrate was prepared shortly before spraying. Water suspensions and filtrates were chosen due to their practical application mode. The filtrates are clearer and do not cause problems with the foliar spraying using a sprayer with a nozzle, while in the case of a suspension containing powder particles, it is necessary to strain the suspension twice before using a fine mesh and to apply with a coarse nozzle.

In vitro biological control activity evaluation

The evaluation of biocontrol activity of cinnamon water suspensions and filtrates against the growth of B. cinerea mycelium was done (El-Mougy Nehal et al. 2004). Disks ( $0.5 \mathrm{~cm}$ diameter each) from pure cultures of the pathogenic fungus were placed in the middle of a $90 \mathrm{~mm}$ Petri dish containing PDA with or without the addition of cinnamon water suspensions and filtrates in five replications. Fungi were grown at $23{ }^{\circ} \mathrm{C}$. Mean colony diameter ( $\mathrm{mm}$ ) was measured after 3 and 6 days (i.e. until a control Petri dish was fully covered by the mycelium; the maximum growth was $85 \mathrm{~mm}$ - the diameter of the dish excluding the diameter of the initial culture).

Plant development evaluation in greenhouse conditions

Experiments were performed in pots according to methods developed by the authors. Ten tomato plants (Ozarowska variety) in the 3-4 leaf phase were planted into each pot. Each repetition consisted of five pots. Altogether five repetitions were made. Later, plants were inoculated by foliar spray with a water suspension of $B$. cinerea spores $\left(3.1 \times 10^{5} \mathrm{ml}^{-1}\right), 1 \mathrm{ml}$ per plant. Three and six days after inoculation water filtrates of cinnamon at $0.5 \%$ was sprayed on the plants surface. The control plants were: a) in the first control group, inoculated with $B$. cinerea and sprayed with water; and b) in the second control group, not inoculated and sprayed with cinnamon water filtrates. After an additional 5 days, the foliage lesions were assessed (the presence of $B$. cinerea was verified microscopically). The impact of spraying with cinnamon on plants was evaluated as the above ground fresh weight of plants collected after 3 and 6 weeks of cultivation.
Plant development evaluation in field conditions

The field trial was carried out on a certified organic farm according to methods developed by the authors. Three field tomato varieties (Agro, Country and Hamlet) were used. Seedlings were planted into soil in June, at the 5leaf phase, with five plants from each cultivar used in each repetition. Altogether four repetitions were made for each cultivar. Six sprayings of water cinnamon filtrates $(0.5 \%)$ were performed at $4-5$ day intervals. The controls were not treated with cinnamon filtrates. The number of leaves and branches was assessed after one and three months of planting to evaluate plants development.

Statistical analysis

A one-way analysis of variance (ANOVA) was used to test significance with Tukey-Kramer's post hoc test for multiple comparisons. A $p$ value $<0.05$ was accepted as statistically significant.

\section{Results and discussion}

In the laboratory experiment, the potential of cinnamon water suspensions vs. cinnamon filtrates in reducing $B$. cinerea growth on PDA medium was evaluated. Three days after PDA inoculation the highest inhibition effect of mycelial growth was obtained while using $1 \%$ of cinnamon water suspensions and $1 \%$ of cinnamon filtrates, which reduced the fungus lesion by 64 and $47.8 \%$, respectively (Table 1). Taking into account all the treatments (with water suspension and filtrate and the two concentrations -0.5 and $1 \%$ ), prolongation of the experiment from 3 to 6 days resulted in an average increase of the mycelium lesions diameter from 10.8 to $60.3 \mathrm{~mm}$. In the same time the changes in the effectiveness of the two cinnamon formulations were observed. After 6 days the effect of cinnamon suspensions (both 0.5 and $1 \%$ ) was very weak to none - in fact the statistical analysis proved no curative effect. The positive effect was found using cinnamon filtrates $-0.5 \%$ filtrate concentration decreased $B$. cinerea mycelium growth by $54.4 \%$ and $1 \%$ filtrate gave a lesions reduction by $81.4 \%$ (Table 1). In other words, the best inhibitory effect in an in vitro study was obtained while using $1 \%$ filtrate of cinnamon powder. 
Table 1 The influence of cinnamon water suspensions and filtrates on an average lesion diameter [mm] of $B$. cinerea measured on day 3 and 6 after beginning of in vitro tests

\begin{tabular}{|c|c|c|c|c|}
\hline \multirow[t]{2}{*}{ Treatment (cinnamon formulation) } & \multicolumn{2}{|c|}{3 days after beginning of test } & \multicolumn{2}{|c|}{6 days after beginning of test } \\
\hline & Lesion diameter, mm & Reduction of lesion, $\%$ & Lesion diameter, mm & Reduction of lesion, $\%$ \\
\hline Control & $16.10 \pm 1.29 \mathrm{a}$ & 0.0 & $85.00 \pm 0.00 \mathrm{a}$ & 0.0 \\
\hline $0.5 \%$ water suspension & $10.10 \pm 1.43 \mathrm{a}$ & 37.3 & $76.90 \pm 18.11 \mathrm{a}$ & 9.5 \\
\hline $1 \%$ water suspension & $5.80 \pm 0.84 b$ & 64.0 & $85.00 \pm 0.00 \mathrm{a}$ & 0.0 \\
\hline $0.5 \%$ water filtrate & $13.70 \pm 3.63 \mathrm{a}$ & 14.9 & $38.80 \pm 8.06 b$ & 54.4 \\
\hline $1 \%$ water filtrate & $8.40 \pm 0.65 b$ & 47.8 & $15.80 \pm 2.02 \mathrm{c}$ & 81.4 \\
\hline Averaged data & 10.8 & 40.9 & 60.3 & 36.3 \\
\hline
\end{tabular}

Values in each column followed by the same letter are not statistically different $P=0.05$

Data are presented as mean \pm standard deviation (SD)

In the greenhouse conditions the disease symptoms decreased on the plants treated with cinnamon water filtrates compared to the control plants which were inoculated and sprayed only with water. On average $1.75 \%$ of the plants treated with cinnamon were infected compared to $2.28 \%$ of control plants. Additionally, spraying with cinnamon water filtrates influenced positively the growth of plants. After six weeks of the application the fresh weight of plants treated with cinnamon was significantly higher than the control. Noninoculated plants treated with cinnamon weighed on average $17.17 \mathrm{~g}$ compared to $12.83 \mathrm{~g}$ for the noninoculated control treated with water $(33.8 \%$ increase of mass). Plants inoculated with $B$. cinerea and treated with cinnamon weighed on average $10.50 \mathrm{~g}$ compared to $7.83 \mathrm{~g}$ for the inoculated control treated with water ( $34.1 \%$ increase of plant weight) (Table 2).

In the field experiment the number of leaves on tomato plants counted one month after planting showed a different pattern of development in the grown varieties. Variety Agro decreased number of leaves by $10.3 \%$ showing an inhibitory effect, while varieties Country and Hamlet increased number of leaves by 5.2 and $27.3 \%$, respectively, showing stimulating effect (Table 3). After two months of growth the number of branches on the plants was counted. The varieties Agro and Hamlet showed a positive reaction to cinnamon water suspension spraying and increased number of branches by 15.3 and $19.7 \%$, respectively. In the same time variety Country did not respond to cinnamon spraying - the cinnamon spraying did not affect the number of branches. The vegetative growth response of tomato plants to cinnamon water suspension spraying depended on the phase of plants development and variety.

According to other studies, both in vitro and in planta, essential oils derived from cinnamon proved to have bio-control properties against many pathogens (Siripornvisal et al. 2009; Hyldgaard et al. 2012). Shabana et al. (2015) tested cinnamon essential oil against $B$. cinerea in vitro and noted a significant suppression of the pathogen growth up to 7 days, comparable to the chemical fungicide Topsin M70-WP. Allam et al. (2017) noted that higher concentration of cinnamon completely inhibited the mycelial growth of

Table 2 The average fresh weight ( $\mathrm{g}$ ) of tomato plant inoculated with $B$. cinerea and treated with $0.5 \%$ cinnamon water filtrates in the pot experiment

\begin{tabular}{lllll}
\hline $\begin{array}{l}\text { Number of weeks of tomato } \\
\text { cultivation in pots }\end{array}$ & $\begin{array}{l}\text { Control } \\
\text { (water spraying) }\end{array}$ & $\begin{array}{l}\text { Non-inoculated plants sprayed } \\
\text { with cinnamon filtrate }\end{array}$ & $\begin{array}{l}\text { Inoculated plants } \\
\text { sprayed with tap water }\end{array}$ & $\begin{array}{l}\text { Inoculated plants sprayed } \\
\text { with cinnamon filtrate }\end{array}$ \\
\hline $\begin{array}{l}\text { Tomato fresh weight after } \\
\quad 2 \text { weeks, }\end{array}$ & $2,14 \pm 0.17 \mathrm{a}$ & $2,09 \pm 0.11 \mathrm{a}$ & $1,71 \pm 0.14 \mathrm{a}$ & $1,85 \pm 0.14 \mathrm{a}$ \\
$\begin{array}{l}\text { Tomato fresh weight after } \\
\quad 6 \text { weeks }\end{array}$ & $12.83 \pm 0.87 \mathrm{~b}$ & $17.17 \pm 1.07 \mathrm{a}$ & $7.83 \pm 0.62 \mathrm{c}$ & $10.50 \pm 1.12 \mathrm{~b}$ \\
\hline
\end{tabular}

Values in each row followed by the same letter are not statistically different $P=0.05$

Data are presented as mean \pm standard deviation (SD) 
Table 3 The influence of cinnamon water filtrate ( $0.5 \%)$ on vegetative development of tomato plants after 1 month (July) and 3 months (September) of application under field conditions

\begin{tabular}{|c|c|c|c|c|c|c|}
\hline \multirow{2}{*}{$\begin{array}{l}\text { Combination } \\
\text { Variety }\end{array}$} & \multicolumn{3}{|c|}{ Control (water spraying) } & \multicolumn{3}{|c|}{ Cinnamon water suspension spraying } \\
\hline & Agro & Country & Hamlet & Agro & Country & Hamlet \\
\hline Number of leaves & $12.6 \pm 0.58 \mathrm{a}$ & $11.6 \pm 0.08 b$ & $11.0 \pm 0.71 b$ & $11.3 \pm 0.55 b$ & $12.2 \pm 0.50 \mathrm{a}$ & $14.0 \pm 0.71 \mathrm{a}$ \\
\hline Number of branches & $14.3 \pm 0.58$ & $17.8 \pm 1.62 \mathrm{a}$ & $12.7 \pm 1.10 b$ & $16.5 \pm 0.55 \mathrm{a}$ & $18.0 \pm 1.65 \mathrm{a}$ & $15.2 \pm 0.82 \mathrm{a}$ \\
\hline
\end{tabular}

Values in each row followed by the same letter are not statistically different $P=0.05$

Data are presented as mean \pm standard deviation (SD)

B. cinerea in vitro. The antifungal potential of cinnamon was confirmed for others pathogens by other authors (Barrera-Necha et al. 2009; Xing et al. 2014; Sarkhosh et al. 2018). The significant antifungal activity of cinnamon oil (both in vitro and in vivo) against various Fusarium species which was proportional to its concentration was shown. In the study by Horváth et al. (2013) the cinnamon oil effectively inhibited mycelial growth of Fusarium head blight of winter wheat in vitro. Jiang et al. (2013), Al-Taisan et al. (2014) and Moraes et al. (2018) examined the inhibitory effects of cinnamon against $S$. sclerotiorum among other essential oils and microelements in in vitro experiments and as soil application. All concentrations of cinnamon completely inhibited the mycelial growth of the fungus. According to Moraes et al. (2018) the result was comparable to a commercial fungicide (thiophanate-methyl +chlorothalonil). Ojaghian et al. (2014) proved that crude extracts of cinnamon are able to reduce in vitro mycelial growth, sclerotial myceliogenic and carpogenic germination of $S$. sclerotiorum. In other studies, during the liquid bioassay, C. zeylanicum was fungicidal against pathogens isolated from banana, including Colletotrichum musae (Berk. \& M.A. Curtis), Lasiodiplodia thebromae (Pat.) Griffon \& Maubl., and Fusarium proliferatum (Matsush.) Nirenberg ex Gerlach \& Nirenberg (Ranasinghe et al. 2002); exerted antifungal activity towards Oidium murrayae Hosag., U. Braun \& Rabindran (Chu et al. 2006) and inhibited conidial germination of Colletotrichum gloesporioides Penz.) Penz. $\&$ Sacc. (Barrera-Necha et al. 2008). In in vitro experiments it was found to have a good mycelial inhibition of the corn $\operatorname{rot} F$. oxysporum f.sp. gladioli (Massey) (Barrera-Necha et al. 2009) and to be highly effective against the growth of Rhizoctonia solani Kühn (Nguyen et al. 2009), as well as to have excellent antifungal activity against early blight of tomato Alternaria solani
Sorauer (Yeole et al. 2014). The investigations of Wang et al. (2014) showed that cinnamon microemulsions had a high in vivo control activity against gray mould of pears $B$. cinerea. The results obtained by the authors also confirmed activity of cinnamon towards control of grey mould in all experimental areas. In presented research water filtrates of cinnamon were more efficient than water suspensions, this fact has two implications, i) it is more applicable to use and, ii) water filtrates should be used in future tests including also chemical analysis of compounds. So far in planta studies on cinnamon as a bio-control agent against $B$. cinerea mainly reported its effectiveness on post-harvest products. It applied to such plants as pears (Wang et al. 2014), citrus fruit (Bouchra et al. 2003), peppers and tomatoes (Kong et al. 2016). In most cases cinnamon oil was used. It had no significant negative effect on plant product qualities such as firmness and colour. The control for decay incidence and lesion diameter was reported to be promising.

While existing literature focuses on antifungal properties of cinnamon, the authors have noticed a significant positive effect of cinnamon filtrate spraying on plant branching in the field experiment. In addition to the fact that the antifungal, antibacterial and pest deterring properties of cinnamon improved the general wellbeing of plants and thus enabled improved growth and branching, there might be another process undergoing on a different level. Therefore, further studies are needed to determine the cause.

To conclude, in laboratory conditions cinnamon water filtrates were more effective against $B$. cinerea than water suspensions and based on literature it seems to be as effective as cinnamon oil. Further studies are required to recognise the mechanisms of cinnamon improving plants growth and development. Cinnamon water filtrates have also proven to be effective in in planta experiments, including both greenhouse and field tomatoes, where the stimulating effect on plant development 
and plant health was confirmed. Formulation of water suspensions and its water filtrates were chosen because of its practical application of being used by growers, while the use of cinnamon oil can be difficult in practise. The inhibitory effect of cinnamon water filtrates may be used for practical application provided the treatments are carried out several times at 4-5 day intervals. This frequency of treatments is sufficient to maintain the inhibitory effect on the developing pathogen. This conclusion has practical implications especially for organic growers who have less plant protection products to use than the farmers growing crops the conventional way.

\section{Compliance with ethical standards}

Conflict of interest The authors declare that they have no conflict of interest.

\section{Research involving human participants and/or animals N/A}

\section{Informed consent N/A}

Open Access This article is distributed under the terms of the Creative Commons Attribution 4.0 International License (http:// creativecommons.org/licenses/by/4.0/), which permits unrestricted use, distribution, and reproduction in any medium, provided you give appropriate credit to the original author(s) and the source, provide a link to the Creative Commons license, and indicate if changes were made.

\section{References}

Allam, S. A., Elkot, G. A., Elzaawely, A. A., \& El-Zahaby, H. M. (2017). Potential Control of Postharvest Gray Mold of Pomegranate Fruits Caused by Botrytis Cinerea. Environment, Biodiversity and Soil Security, 1, 145-156. https://doi.org/10.21608/JENVBS.2017.1822.1011.

Al-Taisan, W. A. A., Bahkali, A. H., Elgorban, A. M., \& ElMetwally, M. A. (2014). Effective influence of essential oils and microelements against Sclerotinia sclerotiorum. International Journal of Pharmacology, 10(5), 275-281. https://doi.org/10.3923/ijp.2014.275.281.

Bakkali, F., Averbeck, S., Averbeck, D., \& Idaomar, M. (2008). Biological effects ofessential oils-a review. Food and Chemical Toxicology, 46, 446-475.

Barrera-Necha, L. L., Bautista-Bańos, S., Flores-Moctezuma, H. E., \& A, R.-E. (2008). Efficacy of essentialoils on the conidial germination, growth of Colletotrichum gloeosporioides (Penz.) Penz. and Sacc and control of postharvest diseases in papaya (Carica papaya L.). Plant Pathology Journal, 7(2), 174-178.

Barrera-Necha, L. L., C, G.-P., \& Garcia-Barrera, L. J. (2009). In vitro antifungal activity of essential oils and their compounds on mycelial growth of Fusarium oxysporum $\mathrm{f}$. sp. gladioli (Massey) Snyder and Hansen. Plant Pathology Journal, 8(1), 17-21.
Bolton, M. D., Thomma, B., \& Nelson, B. D. (2006). Sclerotinia sclerotiorum (Lib.) de Bary: Biology and molecular traits of a cosmopolitan pathogen. Molecular Plant Pathology, 7(1), 116. https://doi.org/10.1111/j.1364-3703.2005.00316.x.

Bouchra, C., Mohamed, A., Mina, I. H., \& Hmamouchi, M. (2003). Antifungal activity of essential oils from several medicinal plants against four postharvest citrus pathogens. Phytopathologia Mediterranea, 42(3), 251-256.

Brenes, A., \& Roura, E. (2010). Essential oils in poultry nutrition: Main effects and modes of action. Animal Feed Science and Technology, 158(1-2), 1-14. https://doi.org/10.1016/j. anifeedsci.2010.03.007.

Chu, Y. L., Ho, W. C., \& Ko, W. H. (2006). Effect of Chinese herb extracts on spore germination of Oidium murrayae and nature of inhibitory substance from Chinese rhubarb. Plant Disease, 90(7), 858-861.

Dean, R., Van Kan, J. A. L., Pretorius, Z. A., Hammond-Kosack, K. E., Di Pietro, A., Spanu, P. D., et al. (2012). The top 10 fungal pathogens in molecular plant pathology. Molecular Plant Pathology, 13(4), 414-430. https://doi.org/10.1111 /j.1364-3703.2011.00783.x.

Dorman, H. J. D., \& Deans, S. G. (2000). Antimicrobial agents from plants: Antibacterial activity of plant volatile oils. Journal of Applied Microbiology, 88(2), 308-316. https://doi.org/10.1046/j.1365-2672.2000.00969.x.

El-Mougy Nehal, S., \& Abdel-Kader Mokhtar, M. (2007). Antifungal effect of powdered spices and their extracts on growth and activity of some fungi in relation to damping-off disease control. Journal of Plant Protection Research, 47(3), 267-278.

El-Mougy Nehal, S., Abd-El-kareem, F. A., El-Gamal, N. G., \& Fotouh, Y. O. (2004). Application of fungicides alternatives for controlling cowpea root rot disease under greenhouse and field conditions. Egyptian Journal of Phytopathology, 32(12), 23-35

Ghalem, B. R. (2016). Essential oils as antimicrobial agents against some important plant pathogenic bacteria and fungi. Plant-microbe interaction: An approach to sustainable agriculture (pp. 271-296). Singapore: Springer.

Harkat-Madouri, L., Asma, B., Madani, K., Said, S., Z, B., Rigou, P., et al. (2015). Chemicalcomposition, antibacterial and antioxidant activities of essential oil of Eucalyptus globulus from Algeria. Industrial Crops and Products, 78, 148-153.

Horváth, A., Kovács, B., \& Nagy, G. (2013). Application of mint and cinamon against Fusarium disease of winter wheat. Episteme Czasopismo Naukowo-Kulturalne, 18(3), 297-304.

Hyldgaard, M., Mygind, T., \& Meyer, R. L. (2012). Essential oils in food preservation: Mode of action, synergies, and interactions with food matrix components. Frontiers in Microbiology, 3. https://doi.org/10.3389/fmicb.2012.00012.

Jiang, Z., Jiang, H., \& Xie, P. (2013). Antifungal activities against Sclerotinia sclerotiorum by Cinnamomum cassia oil and its main components. Journal of Essential Oil Research, 25(6), 444-451. https://doi.org/10.1080/10412905.2013.782475.

Karpouhtsis, I., Pardali, E., Feggou, E., Kokkini, S., Scouras, Z. G., \& Mavragani-Tsipidou, P. (1998). Insecticidal and genotoxic activities of oregano essential oils. Journal of Agricultural and Food Chemistry, 46(3), 1111-1115. https://doi.org/10.1021/jf970822o.

Kocić-Tanackov, S. D., \& Dimić, G. R. (2013). Antifungal activity of essential oils in the control of food-borne fungi growth and 
mycotoxin biosynthesis in food. In A. Méndez-Vilas (Ed.), Microbial pathogens and strategies for combating them: Science, technology and education (pp. 838-849). Badajoz: Formatex Research Center.

Kocic-Tanackov, S., Dimic, G., Levic, J., Tanackov, I., \& Tuco, D. (2011). Antifungal activities of basil (Ocimum basilicum L.) extract on Fusarium species. African Journal of Biotechnology, 10(50), 10188-10195.

Kong, J., Xie, Y. F., Guo, Y. H., Cheng, Y. L., Qian, H., \& Yao, W. R. (2016). Biocontrol of postharvest fungal decay of tomatoes with a combination of thymol and salicylic acid screening from 11 natural agents. Lwt-Food Science and Technology, 72, 215-222. https://doi.org/10.1016/j.lwt.2016.04.020.

Konstantopoulou, I., Vassilopoulou, L., Mavraganitsipidou, P., \& Scouras, Z. G. (1992). Insectidal effects of essential oils - a study of the effects of essential oils extracted from 11 Greek aromatic plants on Drosophila-auraria. Experientia, 48(6), 616-619. https://doi.org/10.1007/bf01920251.

Kowalska, J. (2011). Effects of Trichoderma asperellum [T1] on Botrytis cinerea [Pers.: FR.], growth and yield of organic strawberry. Acta Scientiarum Polonorum, Hortorum Cultus, 10(4), 107-114.

Moraes, S. P. C. B., Bucker, M. W., Bucker, M. W., de Resende Camara, G., Maciel, K. S., de Lima, P. A. M., et al. (2018). Cinnamon and citronella essential oils in the in vitro control of the fungi Aspergillus sp. and Sclerotinia sclerotiorum. African Journal of Agricultural Research, 13(35), 18111815. https://doi.org/10.5897/AJAR2018.13074.

Mourey, A., \& Canillac, N. (2002). Anti-Listeria monocytogenes activity of essential oils components of conifers. Food Control, 13(4-5), 289-292. https://doi.org/10.1016/s09567135(02)00026-9.

Nguyen, V.-N., Seo, D.-J., Park, R.-D., \& Jung, W.-J. (2009). Antimycotic activities of cinnamon-derived compounds against Rhizoctonia solani in vitro. Biocontrol, 54(5), 697-707.

Ojaghian, M. R., Chen, Y., Chen, S., Cui, Z. Q., Xie, G. L., \& Zhang, J. (2014). Antifungal and enzymatic evaluation of plant crude extracts derived from cinnamon and rosemary against Sclerotinia carrot rot. Annals of Applied Biology, 164(3), 415-429. https://doi.org/10.1111/aab.12111.

Pandey, R., Kalra, A., Tandon, S., Mehrotra, N., Singh, H. N., \& Kumar, S. (2000). Essential oils as potent sources of nematicidal compounds. Journal of Phytopathology Phytopathologische Zeitschrift, 148(7-8), 501-502. https://doi.org/10.1046/j.1439-0434.2000.00493.x.

Pessoa, L. M., Morais, S. M., Bevilaqua, C. M. L., \& Luciano, J. H. S. (2002). Anthelmintic activity of essential oil of Ocimum gratissimum Linn. And eugenol against Haemonchus contortus. Veterinary Parasitology, 109(1-2), 59-63. https://doi.org/10.1016/s0304-4017(02)00253-4.

Ranasinghe, L., Jayawardena, B., \& Abeywickrama, K. (2002). Fungicidal activity of essential oils of Cinnamomum zeylanicum (L.) and Syzygium aromaticum (L.) Merr et LMPerry against crown rot and anthracnose pathogens isolated from banana. Letters in Applied Microbiology, 35(3), 208-211. https://doi.org/10.1046/j.1472-765X.2002.01165.x.

Regulation (EC) No1107/2009 of the European Parliament and of the Council of 21 October 2009 concerning the placing of plant protection products on the market and repealing council directives 79/117/EEC and 91/414/EE' (2009) E. Commission.
Remlein-Starosta, D., Krzymińska, J., Kowalska, J., \& Bocianowski, J. (2016). Evaluation of yeast-like fungi to protect Virginia mallow (Sida hermaphrodita) against Sclerotinia sclerotiorum. Canadian Journal of Plant Science, 96(2), 243-251.

Rota, C., Carraminana, J. J., Burillo, J., \& Herrera, A. (2004). In vitro antimicrobial activity of essential oils from aromatic plants against selected foodborne pathogens. Journal of Food Protection, 67(6), 1252-1256. https://doi.org/10.4315/0362028x-67.6.1252.

Sarkhosh, A., Schaffer, B., Vargas, A. I., Palmateer, A. J., Lopez, P., \& Soleymani, A. (2018). In vitro evaluation of eight plant essential oils for controlling Colletotrichum, Botryosphaeria, Fusarium and Phytophthora fruit rots of avocado, mango and papaya. Plant Protection Science, 54(3), 153-162. https://doi.org/10.17221/49/2017-pps.

Shabana, Y. M., El-Boray, M. S. S., Mustafa, M. F. M., \& AlJuboori, G. A. R. M. (2015). Antifungal activity of plant extracts, essential oils, and microbial culture filtrates against Botrytis cinerea in-vitro. Journal of Plant Protection and Pathology Mansoura University, 6, 1297-1311.

Sikes, A., Yang, T., Richardson, M., \& Ehioba, R. (2005). Antifungal activity of volatile oil of mustard (VOM) (No.Natick/TR-05/007), Army Natick Research Development and Enginering Center MA (p. 33). Fort Belvoir: Defense Technical Information Center.

Siripornvisal, S., Rungprom, W., \& Sawatdikarn, S. (2009). Antifungal activity of essential oils derived from medicinal plants against gray mold (Botrytis cinerea), Asian Journal of Food and Agro-Industry, (Special Issue) (pp. 229-223).

van Kan, J. A. L. (2006). Licensed to kill: The lifestyle of a necrotrophic plant pathogen. Trends in Plant Science, 11(5), 247-253. https://doi.org/10.1016/j.tplants.2006.03.005.

Wang, Y. F., Zhao, R. P., Yu, L., Zhang, Y. B., He, Y., \& Yao, J. (2014). Evaluation of cinnamon essential oil microemulsion and its vapor phase for controlling postharvest gray mold of pears (Pyrus pyrifolia). Journal of the Science of Food and Agriculture, 94(5), 1000-1004. https://doi.org/10.1002/jsfa.6360.

Williamson, B., Tudzynski, B., Tudzynski, P., \& van Kan, J. A. L. (2007). Botrytis cinerea: The cause of grey mould disease. Molecular Plant Pathology, 8(5), 561-580. https://doi. org/10.1111/j.1364-3703.2007.00417.x.

Wilson, C. L., Solar, J. M., ElGhaouth, A., \& Wisniewski, M. E. (1997). Rapid evaluation of plant extracts and essential oils for antifungal activity against Botrytis cinerea. Plant Disease, 81(2), 204-210. https://doi.org/10.1094/pdis.1997.81.2.204.

Xing, Y., Li, X., Xu, Q., Yun, J., \& Lu, Y. (2010). Antifungal activities of cinnamon oil against Rhizopus nigricans, Aspergillus flavus and Penicillium expansum in vitro and in vivo fruit test. International Journal of Food Science and Technology, 45(9), 1837-1842. https://doi.org/10.1111/j.1365-2621.2010.02342.x.

Xing, F., Hua, H., Selvaraj, J. N., Zhao, Y., Zhou, L., Liu, X., et al. (2014). Growth inhibition and morphological alterations of Fusarium verticillioides by cinnamon oil and cinnamaldehyde. Food Control, 46, 343-350. https://doi. org/10.1016/j.foodcont.2014.04.037.

Yeole, G. J., Teli, N. P., Kotkar, H. M., \& S, M. P. (2014). Cinnamomum zeylanicum extracts and their formulations control early blight of tomato. Journal of Biopesticides, 7(2), 110.

Zaker, M. (2016). Natural plant products as eco-friendly fungicides for plant diseases control-A review. The Agriculturists, 14(1), 134-141. 